\title{
The University of Eastern Philippines: Green Audit
}

\author{
Myrna Nicol Ogoc
}

\begin{abstract}
Green audit is a holistic perspective of looking into the totality of the actions towards greening the university and is foremost reflected in its policies alongside the organization's profile, the curriculum being the core of the educative process as well as its environment-related programs and projects. These interacting dimensions are geared towards forwarding recommendations for future directions which includes regular assessment and evaluation of the efforts done along environmental preservation and protection. It takes environmentalism as its overriding framework. With it is the underlying concept of advocating for the preservation, restoration and/ or improvement of the natural environment. It embraces risk communication to create consciousness and establish balance relations between humans and the various natural systems on which they depend in such a way that all the components are accorded a proper degree of sustainability which is deeply rooted in the consciousness of its stakeholders.

The descriptive-correlational research design was used in this study to determine the relationship of variables. Documentary analysis was also adopted in trying to measure the extent of integration of environmental themes/ subjects into the curriculum using Rubrics. This research takes into account the examination of UEP system as an organization of its activity to check what it is doing to protect the natural environment and bring about environmental consciousness, which is creating general awareness of environmental issues, their causes and solutions by bringing about changes in the perception to its personnel which will ultimately radiate to a wider spectrum, that is the broader community UEP is a part of.
\end{abstract}

Index Term-Environmental education, environmentalism, green audit, sustainable development.

\section{INTRODUCTION}

The threat of environmental problems should no longer be underestimated. There should be a strong campaign reinforced by the educational institute/institutions to minimize the damage generated. Because of the existing environmental problems we are into and the thrust for sustainability, the protection and improvement of the environment have become imperative educational goals. It is also envisioned that within the next decade, a great majority of Filipinos will be imbued with a sense of responsibility to care for, protect for, and enhance environmental quality that is conducive to their wellbeing and supportive of the nation's economic development [1].

It is therefore important that man has an adequate knowledge about the environment in which they live. This depends in large measure, present and future generations to survive, for it requires, and contributes significantly, the

Manuscript received February 4, 2014; revised April 24, 2014.

Myrna Nicol Ogoc is with Environmental Studies Department of the University of Eastern Philippines, Catarman, N. Samar, Philippines (e-mail: myrna_uep@yahoo.com). implementation of environmental education. The education sector is faced with challenges and is expected to initiate changes in the curriculum and give more attention to environmental education. The curriculum should be geared towards the provision of knowledge, skills and values that will help the learners cope and adapt to these changes.

The goal of environmental education is to develop an environmentally literate and responsible citizenry who will ensure the protection and the improvement of the environment, and bring about sustainability, social equity and economic efficiency in the use of the country's natural resources.

Greening the curriculum means ensuring that students are capable of taking on the 21st century challenges of the most serious environmental threats to face humanity, like global warming and climate change, disaster risks, social inequities, unsustainable lifestyles, and the urgent need to switch to a renewable energy-based economy.

Greening the curriculum must be based on the new knowledge, understanding, skills, experiences and attitudes needed to create a generation of graduates who have a grounding in compassion and ethics (the impacts of climate change are hitting poorer nations first); who grasp the science of global warming and the current and impending impacts of climate change; who have a clear understanding of how their health and ecosystems health are interrelated; who know they are a part of Nature; who understand the ecological principles underlying how life works on Earth; who can approach environmental, social and economic problems with solutions focused and who, because they understand the principles and processes of sustainable development (as defined by the United Nations), can become the change needed in the world.

The goal of Environmental Education curriculum is to help individuals become environmentally knowledgeable, skilled and dedicated citizens who are willing to work individually and collectively toward achieving and maintaining the dynamic equilibrium between the quality of life and the quality of the environment [2], [3].

This research is the first attempt in making the UEP School Program to be attuned to the Green Curriculum Model that might offer a breadth and depth of new ways to cover mandated learning outcomes and subscribing the mandate of Republic Act 9512, “An Act to promote Environmental Awareness through Environmental Education and for other Purposes"; Republic Act (R.A.) No. 7722, otherwise known as the "Higher Education Act of 1995"; Republic Act 9729, also known as "Climate Change Act of 2009", and for the purpose of pursuing the policy of the state to protect and advance the right of the people to a balanced and healthful ecology and in recognition of the vital role of the youth in nation building and the role of education to promote national awareness on the importance of natural resources in economic growth, environmental conservation and 
ecological balance towards sustained national development.

Results of this study will serve as a tool in the decision making in the integration of environmental themes into the curriculum at all levels and guide the University officials with inputs and insights that they may adopt to modify or strengthen existing policies, rules and regulations that subscribe the mandate of R.A. 9512 of the commission of Higher Education and other Environmental laws.

This will try to offer a context shift or new lens, not an overhaul of all-new curriculum but placing the earth, environmental solutions and sustainable development at the heart of our teaching, which can be urgently and immediately implemented, that could make it suitable for the planetary emergency we find ourselves in.

\section{The Conceptual Framework of the Study}

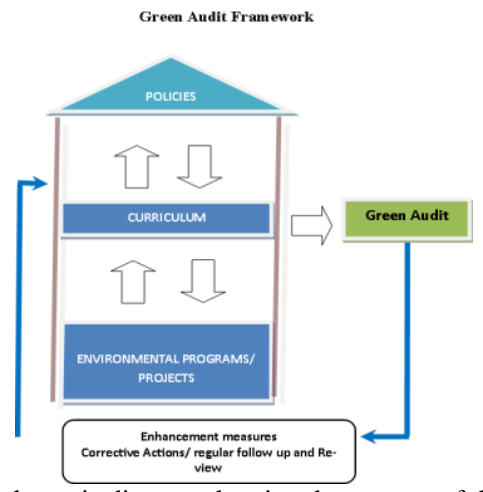

Fig. 1. Schematic diagram showing the concept of the study.

Fig. 1 shows the main tenet of the study wherein it lies in "greening the curriculum" which generally means being open to perspective or sustaining life for all generations as the most important learning objective in the curriculum. This is operationalized in the inclusion of environmental science or studies subjects in all levels of the curriculum; supported with assessable outcomes aligned to their existing curriculum offerings; and that students are well acquainted with environmental themes and their corresponding outcomes manifested in the instruction-related activities, research and community outreach programs of environmental significance.

The theory contends that the different factors are interacting with, influencing and affecting each other as reflected in the degree of interface among them. Hence, the policies, the curriculum and the environment-related programs all affect the learners and the constituents in different domains.

Going down to its workings, comes the role of the powerful mode of expressive communication (in the classroom where the teacher is a potent source of motivation) and in ways that the larger circles of clientele will be able to decode the message which is reinforced by the policies showing how intensely UEP's stance is greening the university. Being also a social institution, UEP has the operative capacities, inclinations, directions, detailed institutional analysis of what is present and what is absent to it can direct and redirect its ways towards meeting its targets and converging with other institutions on preserving the nature. By doing the audit, UEP can have an objective measure as to the whys and wherefores of its environmental advocacy- where it is at the moment (categorized as emerging) and the direction it treads (to reach its target state). The audit would not provide a magical solution to problems in the environmental risk but it supplies the necessary precondition for arriving at those solutions. It provides steps to social policy. It offers reflections as to where UEP is and the directions it is going in the concept of environmental preservation and protection.

\section{Methodology}

\section{A. Research Design}

The descriptive-correlational research design was used in this study to determine the relationship of variables, whether the relationship is perfect, very high, marked or moderate, slight or negligible [4]. It sought to find out the error of correction preferences of the respondents as regards their concern with accuracy, their views about the importance of various feature of greening program in the University school curriculum. Documentary analysis was also adopted in trying to measure the extent of integration of environmental themes/ subjects into the curriculum using Rubrics. This instrument try to present whether its integration is at the initial stage, emerging, developed or highly developed as it relates to the different criterion presented as to its comprehensive listings of themes, assessable outcomes, alignment and student experience. This tool was adopted from rubrics on assessing the Quality of Program Learning outcomes, wherein there is a set of criteria and standards typically linked to learning objectives [5].

\section{B. Research Instrument}

This study was descriptive and inferential in nature that used a survey questionnaire and Rubrics. The survey was undertaken to gather quantitative data as to the level of implementation of environmental-related aspects of school's policy and environment-friendly schools operation and presence of environmental programs and projects. Rubrics were used to measure the degree or extent of integration of environmental themes with consideration of the different criterion as to: comprehensive lists of Environmental Studies (ES) themes, accessible outcomes, alignment, and student experience. Focused group discussions and one-on-one interview were made to selected deans, faculty teaching environmental science and ecology subjects and students taking this subject. This reinforces the data gathering in elucidating the discussion of results.

\section{Scoring and Interpretation of Data}

In scoring for the extent of integration of environmental themes/subjects to existing curriculum Rubrics scoring and interpretation was used. This methodology was done by the researcher by looking into the different syllabus of the different Environmental Science subjects used the multidimensional standardized developmental ratings to determine a holistic score, [4]. In this new sense, a scoring rubric is a set of criteria and standards typically linked to learning objectives. These were including dimensions on which performance is rated, definitions and examples that 
illustrate the attributes being measured and a rating scale for each dimension. Dimensions are generally referred to as criteria, the rating scale as levels and definitions as descriptors [5]. Conclusions were based on a review of each syllabus for those courses identified to have environmental themes/topics included by the researcher. This was complemented with the interview of key departmental representatives, such as Deans, Chairs of department; faculty handling the subject to fully evaluate the alignment of the learning environment and the outcomes is shown below:

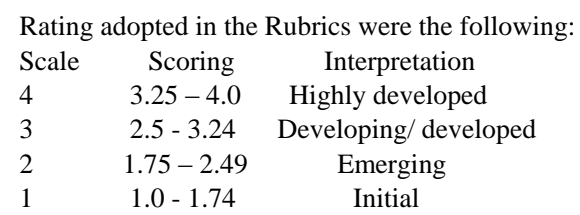

For the scoring and interpretation on the environment related aspects of the schools' policy and environmental-friendly school operations and presence of environment was rated as shown below:

$\begin{array}{ccc}\text { Scale } & \text { Scoring } & \text { Interpretation } \\ 5 & 4.2-5.0 & \text { Very much implemented } \\ 4 & 3.4-4.1 & \text { Implemented } \\ 3 & 2.6-3.3 & \text { Moderately Implemented } \\ 2 & 1.8-2.5 & \text { Less implemented } \\ 1 & 1.0-1.7 & \text { Not implemented }\end{array}$

Mode values were also computed to determine which responses occur most as to the level of integration and implementation.

\section{Population and Sampling}

The population in this study are the deans, heads of schools, department chairperson, selected faculty members and junior and senior students. The sample was the complete enumerations of the deans, heads of school, and chairmen of different department of every college, selected faculty members and junior and senior students in every college teaching environmental subjects. The sample size of this study totalled to 336 respondents for the three campuses including students. Student respondents were computed using the proportional sampling which is enough to represent the total population by using the $10 \%$ margin of error using the formula of [6].

$$
N=1+N e^{\frac{N}{2}}
$$

where: $n=$ is the sample size, $N=$ is the population, $e 2=$ is the margin of error.

\section{E. Data Gathering Procedure}

A combination of primary and secondary data gathering was made. Secondary data were gathered from the Registrar's Office as the UEP's enrolment profile in the three (3) campuses. Checklists were also taken from the different UEP main colleges and schools. Survey questionnaire were distributed to respondents and a one-on-one interview and Focused Group Discussions (FGD) to students and faculty were done to get rapid assessment on the profile of the different colleges/schools; extent of integration of environmental subjects/themes into the curriculum; extent of implementation of environment-related aspects of the school's policy and environment-friendly school operations and presence of environmental programs and projects.

Focused group discussions were used to obtain insights, perceptions, and counter check generated data from the questionnaire.

\begin{tabular}{|c|c|c|c|c|c|c|c|}
\hline \multirow{2}{*}{ Colleges } & \multicolumn{7}{|l|}{ Criterion } \\
\hline & $\begin{array}{l}\text { Comprehensive lists of } \\
\text { themes/focused topics }\end{array}$ & $\begin{array}{l}\text { Assessable } \\
\text { outcomes }\end{array}$ & Alignment & $\begin{array}{l}\text { Student } \\
\text { experience }\end{array}$ & Total & Mean & $\begin{array}{l}\text { Interpretat } \\
\text { ion }\end{array}$ \\
\hline GS & $\begin{array}{l}2.5 \\
(3)\end{array}$ & $\begin{array}{l}2.5 \\
(3)\end{array}$ & $\begin{array}{l}2.7 \\
(3)\end{array}$ & $\begin{array}{l}2.2 \\
(2)\end{array}$ & 9.9 & $\begin{array}{l}2.46 \\
(2)\end{array}$ & Emerging \\
\hline CAFNR & $\begin{array}{l}3.0 \\
(3)\end{array}$ & $\begin{array}{l}2.4 \\
(2)\end{array}$ & $\begin{array}{l}3.2 \\
(3)\end{array}$ & $\begin{array}{l}3.0 \\
(3)\end{array}$ & 11.6 & $\begin{array}{l}2.9 \\
(3)\end{array}$ & $\mathrm{D}$ \\
\hline $\mathrm{CBA}$ & $\begin{array}{l}2.8 \\
(3)\end{array}$ & $\begin{array}{l}2.37 \\
(2)\end{array}$ & $\begin{array}{l}2.8 \\
(3)\end{array}$ & $\begin{array}{l}2.5 \\
(3)\end{array}$ & 10.47 & $\begin{array}{l}2.62 \\
(3)\end{array}$ & Emerging \\
\hline COED & $\begin{array}{l}2.6 \\
(3)\end{array}$ & $\begin{array}{l}2.4 \\
(2)\end{array}$ & $\begin{array}{l}2.8 \\
(3)\end{array}$ & $\begin{array}{l}2.8 \\
(3)\end{array}$ & 10.6 & $\begin{array}{l}2.65 \\
(3)\end{array}$ & Emerging \\
\hline $\mathrm{CoE}$ & $\begin{array}{l}2.6 \\
(3)\end{array}$ & $\begin{array}{l}2.2 \\
(2)\end{array}$ & $\begin{array}{l}2.0 \\
(2)\end{array}$ & $\begin{array}{l}2.2 \\
(2)\end{array}$ & 9 & $\begin{array}{l}2.25 \\
(2) \\
\end{array}$ & Emerging \\
\hline $\mathrm{CN}$ & $\begin{array}{l}2.0 \\
(2)\end{array}$ & $\begin{array}{l}2.0 \\
(2) \\
\end{array}$ & $\begin{array}{l}2.0 \\
(2) \\
\end{array}$ & $\begin{array}{l}2.0 \\
(2)\end{array}$ & 8 & $\begin{array}{l}2.0 \\
(2)\end{array}$ & Emerging \\
\hline $\mathrm{CS}$ & $\begin{array}{l}3.25 \\
(4)\end{array}$ & $\begin{array}{l}2.62 \\
(3)\end{array}$ & $\begin{array}{l}3.25 \\
(4)\end{array}$ & $\begin{array}{l}3.25 \\
(4) \\
\end{array}$ & 12.37 & $\begin{array}{l}3.09 \\
(3)\end{array}$ & $\begin{array}{l}\text { Developin } \\
\mathrm{g}\end{array}$ \\
\hline CVM & $\begin{array}{l}1.6 \\
(1)\end{array}$ & $\begin{array}{l}1.6 \\
(1) \\
\end{array}$ & $\begin{array}{l}1.4 \\
(1) \\
\end{array}$ & $\begin{array}{l}1.6 \\
(1)\end{array}$ & 6.2 & $\begin{array}{l}1.6 \\
(1)\end{array}$ & Initial \\
\hline UEPLHS/ ULES & $\begin{array}{l}2.4 \\
(2)\end{array}$ & $\begin{array}{l}2.6 \\
(3)\end{array}$ & $\begin{array}{l}2.2 \\
(2)\end{array}$ & $\begin{array}{l}2.0 \\
(2)\end{array}$ & 9.2 & $\begin{array}{l}2.3 \\
(2)\end{array}$ & Emerging \\
\hline UEP LAOANG & $\begin{array}{l}2.6 \\
(3)\end{array}$ & $\begin{array}{l}2.5 \\
(3)\end{array}$ & $\begin{array}{l}2.5 \\
(3)\end{array}$ & $\begin{array}{l}2.2 \\
(2)\end{array}$ & 9.8 & $\begin{array}{l}2.45 \\
(2)\end{array}$ & Emerging \\
\hline UEP CATUBIG & $\begin{array}{l}2.2 \\
(2)\end{array}$ & $\begin{array}{l}2.2 \\
(2)\end{array}$ & $\begin{array}{l}2.5 \\
(3)\end{array}$ & 2.2 & 9.1 & $\begin{array}{l}2.3 \\
(2)\end{array}$ & Emerging \\
\hline Grand Mean & $\begin{array}{c}2.52 \\
(3)\end{array}$ & $\begin{array}{l}2.29 \\
(2)\end{array}$ & $\begin{array}{l}2.47 \\
(2)\end{array}$ & $\begin{array}{l}2.43 \\
(2)\end{array}$ & 9.62 & $\begin{array}{l}2.41 \\
(2)\end{array}$ & \\
\hline
\end{tabular}

TABLE I: SUMMARY DiSTRIBUTION ON THE EXTENT OF IMPLEMENTATION OF ENVIRONMENTAL RELATED ASPECTS OF THE SCHOOL'S POLICY

Note: Number enclosed in parenthesis is the mode values. 
TABLE II: SUMMARY DiSTRIBUTION ON THE EXTENT OF IMPLEMENTATION OF ENVIRONMENTAL RELATED ASPECTS OF THE SCHOOL'S POLICY A) GENERAL POLICY OF THE UNIVERSITY

\begin{tabular}{|c|c|c|c|}
\hline & Mean & Mode & Interpretation \\
\hline $\begin{array}{l}\text { - Environmental protection is part of the college vision/mission } \\
\text { statement? }\end{array}$ & 3.38 & 3 & Moderately Implemented \\
\hline - EE is a specific mission of the school? & 2.87 & 3 & Moderately Implemented \\
\hline - The college have an overall environmental policy & 2.88 & 3 & Moderately Implemented \\
\hline $\begin{array}{l}\text { - The Environmental policy of the school is communicated to constituents } \\
\text { in the school }\end{array}$ & 3.03 & 3 & Moderately Implemented \\
\hline $\begin{array}{l}\text { - Environmental considerations are included in the criteria for decision } \\
\text { making }\end{array}$ & 3.05 & 3 & Moderately Implemented \\
\hline $\begin{array}{l}\text { - There is a person or a committee responsible for environmental projects } \\
\text { and programs in the school }\end{array}$ & 2.77 & 3 & Moderately Implemented \\
\hline $\begin{array}{l}\text { - The school's implementation of EE is reflected in the quality of the } \\
\text { school environment? }\end{array}$ & 3.23 & 3 & Moderately Implemented \\
\hline $\begin{array}{l}\text { - The school's implementation arrangements received support from the } \\
\text { school communities through MOA or other means }\end{array}$ & 2.73 & 3 & Moderately Implemented \\
\hline Mean & 2.99 & 3 & Moderately Implemented \\
\hline
\end{tabular}

B) PERSONNEL Policy

\begin{tabular}{|l|l|l|l|}
\hline $\begin{array}{l}\text { Environmental considerations is part of the performance appraisal system of: } \\
\text { - Faculty }\end{array}$ & Mean & Mode & Interpretation \\
\cline { 2 - 4 } & 2.45 & 2 & Slightly Implemented \\
\hline $\begin{array}{l}\text { - Department heads/supervisors? } \\
\text { - Support staff? }\end{array}$ & 2.62 & 3 & Moderately Implemented \\
\hline $\begin{array}{l}\text { Personnel are required to practice environment oriented activities like: } \\
\text { - waste reduction and management }\end{array}$ & 2.63 & 3 & Moderately Implemented \\
\hline $\begin{array}{l}\text { - use of nontoxic materials } \\
\text { - Conduct of/involvement in community based projects related to environment }\end{array}$ & 2.86 & 3 & Moderately Implemented \\
\hline Mean & 2.77 & 3 & Moderately Implemented \\
\hline
\end{tabular}

C) PURCHASING POLICY

\begin{tabular}{|c|c|c|c|}
\hline \\
\hline $\begin{array}{l}\text { The college has a purchasing policy which in general, rejects products which are harmful to the } \\
\text { environment like: }\end{array}$ & Mean & Mode & Interpretation \\
\hline - Styrofoam & 2.45 & 2 & Slightly Implemented \\
\hline - CFC aerosols & 2.45 & 2 & Slightly Implemented \\
\hline - Oil-based paints & 2.58 & 2 & Slightly Implemented \\
\hline - Fire extinguishers using halons & 2.53 & 2 & Slightly Implemented \\
\hline - High phosphate detergents & 2.46 & 2 & Slightly Implemented \\
\hline - Plastics & 2.72 & 3 & $\begin{array}{l}\text { Moderately } \\
\text { Implemented }\end{array}$ \\
\hline - Synthetic pesticides & 2.66 & 3 & $\begin{array}{l}\text { Moderately } \\
\text { Implemented }\end{array}$ \\
\hline \multicolumn{4}{|l|}{ The college has a purchasing policy which in general, favored the use or purchase of the following: } \\
\hline - Recycled & 3.01 & 3 & $\begin{array}{l}\text { Moderately } \\
\text { Implemented }\end{array}$ \\
\hline - Recyclable & 2.8 & 3 & $\begin{array}{l}\text { Moderately } \\
\text { Implemented }\end{array}$ \\
\hline - Nontoxic & 2.87 & 3 & $\begin{array}{l}\text { Moderately } \\
\text { Implemented }\end{array}$ \\
\hline - Biodegradable & 3.11 & 3 & $\begin{array}{l}\text { Moderately } \\
\text { Implemented }\end{array}$ \\
\hline - Rechargeable & 3.12 & 3 & $\begin{array}{l}\text { Moderately } \\
\text { Implemented }\end{array}$ \\
\hline - Refillable & 3.23 & 3 & $\begin{array}{l}\text { Moderately } \\
\text { Implemented }\end{array}$ \\
\hline - Secondhand & 2.91 & 3 & $\begin{array}{l}\text { Moderately } \\
\text { Implemented }\end{array}$ \\
\hline - Reusable & 3.05 & 3 & $\begin{array}{l}\text { Moderately } \\
\text { Implemented }\end{array}$ \\
\hline \multicolumn{4}{|l|}{ Packaging is required from suppliers in: } \\
\hline - Bulk packaging (individual packaging not required & 2.94 & 3 & $\begin{array}{l}\text { Moderately } \\
\text { Implemented }\end{array}$ \\
\hline - Individual packaging even when buying in bulk & 2.49 & 2 & Slightly Implemented \\
\hline Mean & 2.76 & 3 & $\begin{array}{l}\text { Moderately } \\
\text { Implemented }\end{array}$ \\
\hline Grand Mean & 2.84 & & $\begin{array}{l}\text { Moderately } \\
\text { Implemented }\end{array}$ \\
\hline
\end{tabular}




\section{F. Statistical Treatment of Data}

To describe the variables, frequency counts, percentages and weighted means was computed. To test the relationship between the independent variables and the dependent variables the multiple regression analysis was used.

\section{G. Extent of Integration of Environmental Subjects/Themes into Existing Courses}

Table I presents the extent of integration of environmental subject/themes into the existing courses. Frequent responses of the three campuses in terms of the comprehensive list of themes/focused topics, assessable outcomes, alignment, and student experience are considered "emerging" when the grand mean of 2.33 was taken from all the colleges and schools, which imply that the whole University system has already started to integrate environmental themes into the curriculum. Most of the responses from the three (3) campuses appear to be between 2 and 3 scores which mean that the University is progressing in terms of integrating environmental themes into their existing curriculum.

\section{H. Extent of Implementation of Related Aspect in Terms of School Policy}

\section{1) General policy of the university}

The general policy of the university regarding the extent of implementation was analyzed based on the responses of the three campuses of the university and were assessed by the students and dean, department chairperson, and faculty teaching environmental science and ecology in their respective campuses. In Catubig and Laoang campuses, both the students and faculty frequent responses fall under level 3 which indicated "moderately implemented". However in UEP Main campus, both students and the faculty indicated "implemented", or most of their responses were under level 4.

'Moderately implemented' extent of implementation of environmental related aspects in terms of the general policy means that the inclusion of an over-all policy on environmental protection as part of the VMGO of each college; communicating these to constituents in the school and as criteria for decision-making are not done yet in other colleges.

\section{2) Personnel policy}

Regarding the personnel policy in Catubig campus, a majority of the students responses are within level 2 which indicated "slightly implemented" while a majority of the faculty responses are in level 3 which indicated "moderately implemented". In Laoang a campus, majority of the student responses fall under level 3 which indicated "moderately implemented" while a majority of faculty indicated "slightly implemented. Likewise in the UEP main campus, most frequent responses of both the students and faculty are level 3 which indicated "moderately implemented. Considering the three campuses of the University of Eastern Philippines, the implementation of environmental related aspects in terms of personnel policy is "moderately implemented". This means that environmental considerations being part of the performance appraisal system of every faculty, department head and support staff; and requiring them to practice environment-oriented activities are not much implemented.

\section{3) Purchasing}

Regarding purchasing policies which are harmful to environment, like Styrofoam, CFC aerosols, oil based paints, fire extinguishers using halons, high phosphate detergents, plastics, and synthetic pesticides, frequent responses of the students and faculty of the three campuses of the University were on level 2 only which is rated "slightly implemented" while the purchasing policy which in general, favored the use or purchases of the following recycled, recyclable, non-toxic, biodegradable, rechargeable, refillable, second hand and reusable is "moderately implemented", attributed by level 3 frequent responses of both faculty and students. However, some of the respondents in the three campuses indicated "moderately implemented" on item 'regarding packaging is required from suppliers in bulk packaging and individual packaging when buying in bulk'. Colleges favored the use of products which are not environment-friendly considering that their responses are "moderately implemented". Generally, the extent of implementation of related aspects in terms of school policy is rated "moderately implemented" which means that the University has strengthened its implementation on this aspect as supported by all environmental policies of the university that were implemented even before 1992.

Table II presents the summary distribution of the extent of implementation of environmental related aspects in terms of school policy in the three campuses of the University of Eastern Philippines.

\section{CONCLUSION}

Regarding the extent of integration of environmental subjects/themes into existing courses, five colleges of the UEP main campus, Laoang, UEP Catubig, and UEP-Laboratory High School (ULHS)/University Laboratory Elementary School (ULES) faculty members indicated "emerging", attributed by their frequent responses of level 2 while two colleges namely College of Science, and College of Agriculture, Fishery and Natural Resources (CAFNR) were "developed", which fall under level 3 responses and one college, College of Veterinary Medicine (CVM) was "initial", level 1. This implies that colleges are starting/started to include environmental science and ecology subjects in their curriculum. Other colleges have incorporated environmental themes into their curriculum not environment -specific but discipline -specific. Topics on ecology and care for the environment are treated in some subjects only.

On the implementation of environmental related aspects of schools policy, all campuses indicated "moderately implemented" as regards to general policy of the university, personnel policy, and purchasing policy. This means that the University have started implementing general environmental policies.

As to environment-friendly school operations and presence of environmental programs, most frequent responses of the three campuses is level 3 which indicated "moderately implemented". This means that buildings and ground greening, light and electricity conservation, water 
utilization and conservation, paper conservation, canteen operations, general waste management, and air quality were already taken into compliance.

It can be noted that the implementation of environmental related aspects of school policy of the University of Eastern Philippines was "moderately implemented", as a result of the majority of their responses under level 3. As to the environment-friendly schools operations and presence of environmental programs and projects, majority of the faculty and students of three campuses of the university responses is level 3 which indicated also "moderately implemented". This means that the University is responding positively to local environmental problems even before 1992.

The level of Integration of environmental themes and the profile of the colleges, number of trainings of faculty, research and extension projects, awards and citations received were important considerations of an institutions' effort to increase the level of integration of environmental themes and subjects into the curriculum. This imply that the greater emphasis the university put into the profile of the colleges in terms of trainings attended, research and extension projects supported, awards and citations received by the faculty, the greater is the extent of integration made by faculty.

As to the extent of implementation of policies and guidelines and the profile of the colleges, Association of Accrediting Universities in the Philippines (AACUP), [7] has nothing to do with the level or extent of implementation of these policies and guidelines. However it is the number of faculty teaching and environmental science and ecology, number of trainings attended, research and extension projects, awards and citations that influence much on how the college and the University as a whole increases the extent of implementation of policies of the University. This implies that even if a particular college or school attain a higher level in the AACUP accreditation, it has nothing to do with the implementation of the University's environmental policy implementation.

Regarding the relationships between the environment-friendly operations and presence of environmental programs and the profile of the different colleges and schools, the significantly-related were the level of AACCUP accreditation, number of personnel teaching environmental science and ecology, number of trainings attended related to environment, research and extension projects relevant to environment and awards and citations received, while the numbers of faculty members with educational background related to environmental science and ecology were found to be not significant. This implies that even though a particular college or University will have higher number of faculty members with educational background related to environmental science and ecology; this does not mean that the level of implementation of environment -friendly school operations and presence of environmental programs and projects will also increase.

\section{REFERENCES}

[1] L. Memije-Cruz. (2012). Greening the curriculum. [Online]. Available: http://www.allvoices.com/contributed-news/6544470-

[2] Environmental Education Guide, 1999, Asian Development Bank, TA No. 1385-PHI, the Consortium of Colombo Plan Staff College for Technician Education and Madecor Environmental Management Systems, Inc.

[3] Environmental Education in the Philippines. [Online]. Available: http://ww.eduphil.org/environmental-education-in-the-philippines.htm

[4] L. Calmorin, Statistics in Education and Sciences with Application to Research, Rex Bookstore, Inc., 1997.

[5] Grubb, Rubrics on Assessing the Quality of Program Learning outcomes, 1981.

[6] C. Sevilla et al., An Introduction to Research Methods, Quezon City: Rex Printing Company, Inc. 1988.

[7] Accrediting Agency of Chartered Colleges and Universities in the $\begin{array}{lll}\text { Philippines, } & \text { (AACCUP). } & \text { Anline]. }\end{array}$ http://www.aaccupqa.org.ph/Accreditation.html

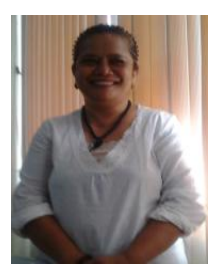

Myrna Nicol Ogoc has over 28 years' experience in teaching and community organizing. She is an accredited environmental impact assessment / EIS preparer and an active adviser and environmental consultant for Critical Environmental Projects of Private institutions/ businesses, Local Government Units/ NGOS and Peoples' Organization (PO); she has considerable experience in conducting community resource assessments; coastal ecological assessments and profiling; water quality assessments, pollution and toxicological studies; forming and developing cooperatives; conceptualizing and developing projects, designing, preparing and implementing training modules; formulating operational policies at the organizational level; planning, managing, monitoring and evaluation of environmental projects and cooperatives, income generation projects, and other environmental related education and advocacy programs. Conduct trainings and seminars related to environmental issues and problems especially climate change and solid waste, cooperative formation and development, leadership, internal control and values education.

She is the director for Center for Environmental Studies and Advocacy; an associate professor and chairman of Environmental Science Program, College of Science, University of Eastern Philippines, Catarman Northern Samar, Philippines. She is a graduate of $\mathrm{PhD}$ in educational management, University of Eastern Philippines; a candidate in $\mathrm{PhD}$ in environmental science, University of the Philippines; Post-doctoral course in Total Quality Management in Higher Education; master of science in agrometeorology and environmental studies, UP Los Banos; and a bachelors degree holder in agricultural engineering at the University of Eastern Philippines. She is an awardee as Climate Change Hero and instrumental in the UEP Sustainable and Eco-friendly University Award as Champion and an awardee in several regional and Provincial Advocacies in Coastal and Marine Ecosystems.

Dr. Myrna Nicol Ogoc is a member of the Foundation for Philippine Environment (FPE) as one of the Regional Advocacy committee member in the region; Environmental Educators Network of the Philippines; Philippine Science Educators Network; and several other local and national organizations. She is a researcher and an extentionist and have published and presented several researches both in local, national and international publications. 